Original Article

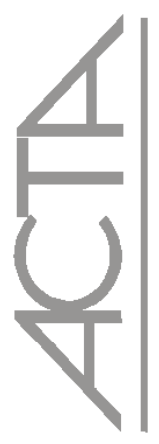

\title{
Family considerations about the decision to refuse organ donation*
}

\author{
Ponderações de familiares sobre a decisão de recusar a doação de órgãos \\ Ponderaciones de familiares sobre la decisión de rechazar la donación de órganos
}

\author{
Gerlene Grudka Lira ${ }^{1}$, Cleide Maria Pontes ${ }^{2}$,Janine Schirmer3, Luciane Soares \\ de $\operatorname{Lima}^{4}$
}

\begin{abstract}
Objective: To understand the social representations that guided family decision to refuse organ donation for transplant and to identify the actions of the social environment that influenced this refusal. Methods: Qualitative study using a descriptive exploratory design. Nine family members were interviewed between February and August 2009, whose family member death had been reported regularly by the Transplantation Center of Pernambuco. The statements underwent content analysis in semantic categories. Results: Three semantic categories emerged which supported this study: The care and management model of health services is critical in refusing the donation; the body is inviolable; and belief in the possibility of returning to life-heart as the source of life and faith strengthening hope. Conclusion: The participants' refusal to organ donation has been supported in the context of service provided and hospital care received, as well as cultural and religious values.
\end{abstract}

Keywords: Tissue and organ procurement; Brain death; Attitude; Family

\section{RESUMO}

Objetivos: Compreender as representações sociais que nortearam a decisão familiar de recusar a doação de órgãos para transplante e identificar as ações do entorno social que influenciaram esta recusa. Métodos: Estudo de natureza qualitativa, utilizando um desenho descritivo exploratório. Foram entrevistados nove familiares, entre fevereiro e agosto de 2009, cuja morte do parente havia sido notificada regularmente pela Central de Transplantes de Pernambuco. Os depoimentos obtidos sofreram análise de conteúdo na modalidade temática. Resultados: Emergiram três temas que fundamentaram este estudo: o modelo de atenção e gestão dos serviços de saúde é decisivo na recusa da doação; o corpo é inviolável e crença na possibilidade de retorno à vida - coração como sede da vida e fé reforçando a esperança. Conclusão: A recusa dos participantes para doação de órgãos esteve amparada no contexto do atendimento e do acolhimento hospitalar recebido, bem como em valores culturais e religiosos. Descritores: Obtenção de tecidos e órgãos; Morte encefálica; Atitude; Família

\section{RESUMEN}

Objetivos: Comprender las representaciones sociales que orientaron la decisión familiar de rechazar la donación de órganos para transplante e identificar las acciones del entorno social que influenciaron para esta recusación. Métodos: Estudio de naturaleza cualitativa, en el que se utilizó un dibujo descriptivo exploratorio. Fueron entrevistados nueve familiares, entre febrero y agosto del 2009, cuya muerte del pariente había sido notificada regularmente por la Central de Transplantes de Pernambuco. Las declaraciones obtenidas fueron sometidas a análisis de contenido en la modalidad temática. Resultados: Emergieron tres temas que fundamentaron este estudio: el modelo de atención y gestión de los servicios de salud es decisivo en la recusación de la donación; el cuerpo es inviolable y la creencia en la posibilidad de retorno a la vida - corazón como sede de la vida y fe que reforzó la esperanza. Conclusión: El rechazo de los participantes a la donación de órganos estuvo amparada en el contexto de la atención y acogida hospitalaria recibido, así como en valores culturales y religiosos.

Descriptores: Obtención de tejidos y órganos; Muerte encefálica; Actitud; Família

\footnotetext{
* Research conducted at the Federal University of Pernambuco - UFPE - Recife (PE), Brazil.

${ }^{1}$ Nurse. Master's degree, Graduate Program in Health Sciences, Federal University of Pernambuco - UFPE - Recife (PE), Brazil.

${ }^{2}$ Full Professor, Department of Nursing, Federal University of Pernambuco - UFPE - Recife (PE), Brazil.

${ }^{3}$ Full Professor of Paulista School of Nursing, Federal University of Sao Paulo - UNIFESP - Sao Paulo (SP), Brazil.

${ }^{4}$ Full Professor, Department of Nursing, Federal University of Pernambuco - UFPE - Recife (PE), Brazil.
} 


\section{INTRODUCTION}

The family refusal for organ donation is a limiting factor for transplant. Among other problems, the underreporting of patients diagnosed with brain death to regulatory centers, despite their obligation provided by Brazilian law; lack of policy on continuing education for health professionals about the donation transplant process and high clinical index contraindication to the donation ${ }^{(1,2)}$.

According to data from the Brazilian Registry of Transplant, in 2010, the absence of family member authorization accounted for $25.8 \%$ of organs not donated, and medical contraindication for $14.2 \%{ }^{(3)}$. Family refusal, although not the only barrier to increase the availability of organs and tissues for transplant, is modifiable through educational and informative incentives in a scenario where the donation is socially recognized, as a gesture of altruism and solidarity ${ }^{(4)}$.

There are several reasons given by families for organ donation refusal: the lack of understanding of Brain Death diagnosis; lack of knowledge about the wishes of the dead person; inadequate family interview; bodily integrity maintainance and religious issues, among others ${ }^{(5)}$.

The theory of social representations is a conceptual tool that allows the understanding of how social construction of reality is made. This theory assumes that individuals and groups actively construct representations of relevant social objects, based on several beliefs that are constantly circulating in our society ${ }^{(4.6)}$.

Actions taken by people, therefore, are linked to their beliefs. They resort to a set of beliefs to make decisions and take statements which may be linked to agreement or disagreement, the truth or falsity. This process allows the individual or group to make sense of their behavior and understand reality through their own reference system ${ }^{(6)}$. Thus, organ donation is more than an individual attitude and decision, it involves the shared dynamic understanding based on the interaction of the individual with society.

In this context, in order not only to understand the refusal of family members regarding organ donation but also contribute to address actions to increase the supply of organs and tissues for transplant, this study was conducted by the following question: what are the social representations which are leading to the refusal of organ donation?

\section{OBJECTIVE}

To understand which social representations guided family members in the decision to refuse the organ donation for transplant; and to identify the actions of the social environment that influenced this refusal.

\section{METHODS}

Based on the study problem, the family refusal for organ donation, we chose to use a qualitative method through a descriptive and exploratory design. The theoretical framework was based on the Social Representations Theory $^{(7)}$.

This study was conducted with nine family members of potential organ donors who have not consented to donation, regularly reported by the Central Notification, Organ Procurement and Distribution (CNOPD) of the State of Pernambuco.

The determined minimum time between the occurrence of death and the family member interview for data collection was three months, considered minimum for the experience of mourning. The criterion for determining this range was based on studies with similar topic ${ }^{(8,9)}$. No time limit was established for contact by the lack of literature support.

For inclusion in the study, the definition of family member interviewed followed the recommendations in the Brazilian Federal Law No. 10.211/2001, which determines that the family member must be related to the dead person at least within the second degree as the legally responsible person for authorizing the donation of organs and tissues ${ }^{(10)}$.

The invitation to participate in the research was initially done through telephone contact and invitation letters, however, through Family Health Units and Community Health Workers, it was possible to access and make the research reliable for study participation. Initially, 14 families were selected, only in the metropolitan area of Recife, nevertheless, seven refused to participate or did not respond to the invitation letters.

Data were collected at the families homes in the period between February and August 2009, after approval of the research project by the Ethics Committee on $\mathrm{Hu}$ man Research of the Center for Health Sciences, Federal University of Pernambuco, under Protocol 292/2008 and after obtaining the signature of a Consent Form.

The sample design was intentional and the criterion adopted for its closure was the theoretical saturation of the material obtained ${ }^{(11)}$. Individuals were randomly included as they accepted to participate, as long as they met the inclusion criterion.

The technique used to obtain the data was semistructured interviews, conducted based on two questions: How was the moment of decision regarding organ donation of your deceased relative? What contributed to your decision?

The statements were recorded via an audio recorder and fully transcribed immediately after the interviews, both procedures were performed by one of the researchers. 
In order to identify statements and preserve anonymity of individuals, the interviews were related in chronological order of their completion, being referred to as E1, E2, E3, and so on. The ellipses were used for discourses excerpts and parentheses for further information.

Data analysis was based on content analysis in the thematic modality proposed by Bardin which consists of a set of techniques for communications analysis, which uses the division of the text into units, as analog regrouping, categorized by semantic, so that subjects with the same meaning are grouped into a common category ${ }^{(12)}$.

From the data collected, we conducted a first reading of the material produced by the participants, called skimming, and later, a deep in of the material in order to extract classification criteria of the results and to form semantic categories ${ }^{(12)}$.

The set of interviews was excerpt by a "grid" of categories designed, allowing the observation of the frequency of extracted themes, thereafter, the results were discussed in light of the theory of social representations, as well as the literature review.

\section{RESULTS}

The nine family members who participated in the study were: between 18 and 70 years old; from a Christian religion; from lower middle class; lived in the suburbs of the metropolitan region of Recife and experienced the process of brain death of their family members in public and private hospitals.

The analysis of representations that emerged from discourses were: The care and management model of health services is critical in refusing the donation; the body is inviolable; and belief in the possibility of returning to the life-heart as the source of life and faith strengthening hope.

\section{The care and management model of health} services is critical in refusing the donation

In this representation, we rescued the participants statements regarding the association between medical care provided to the family and its influence in refusing to consent to organ donation.

We observed a correlation between the care received by the family member and the refusal to donate. Even those who did not relate one matter to another remembered the lack of adequate infrastructure, lack of priority in attendance, the fact they had not received the necessary clarifications, and the distancing in the relationship between healthcare professionals - patients - family, even in a private hospital. These findings are highlighted in the following excerpts from the interviews:

...They were not (bealth team) concerned with the welbeing of the patient or family ... they were just trying to... preserve the organs ... he was attached to the machines, but he was not in ICU, he was not taken care ... E3

... We decided not to donate the organs ... due to lack of care... lack of relief ... E9

These statements clearly demonstrate gaps in the implementation of the present model of care and service management. The user does not have access to a welcoming service, which is translated into dissatisfaction with the care received.

Due to a scarcity of information about the behavior and prognosis of the patient, it became clear to the family how mechanical health professionals actions were, appearing to be concerned only in organ donation.

We did not have that care(emphasis) ... we missed...their commitment to try to save him ... after brain death was said, they instantly knew ... call the family, ... to donate ... E8

The way the process of organ donation for transplant was conducted raised doubts about the veracity and credibility of the Transplants system for these families. They feared that the physician`s shady interest was not to care for the welbeing of the patient. The cultural imaginary of organ trafficking surfaced, occurring loss of trust in the process, as highlighted below:

... And another thing ... the mistrust that existed ... these organ sales ... People ... are not sure if those organs go exactly to that person ... E2

... they only came to ask if we wanted to donate, right away... then the other doctor said ... they sell the organs ... I freakead out ... E4

\section{The body is inviolable}

This theme was unveiled in the statements of the participants as a significant consideration for families who have not consented to donation. For three families it was evident as the main reason, and for two other families, even if it was not the key factor, it was considered before the decision. The refusal was related to the importance of maintaining the integrity of the body, reinforcing the cult of the body present in society, as expressed in the excerpts below:

... They thought maybe he would be deformed .... E2

... he said he did not want to donate, so, there will be no donation, ... he said that if he came as a whole, he had to go as a whole, we weren't supposed to donate anything, no. E6

Collaborating with the aspect of maintaining the integrity of the body and the consequent refusal to organ donation, is the association between people's unpreparedness to face the situations of loss, individual religiosity and culture, as well as the imaginary of body mutilation. We can observe in the statements described below:

... I think they just do not have the culture, ... my father-in-law and my mother-in-law are semi illiterate people ...they thought that they would open her and take everything, even her eye .... E7 
We were deciding (to donate), but our aunt didn't want us to ... Because she is Christian (Protestant religion), ... she said the way she came, she'll go ... E5

\section{Belief in the possibility of returning to life - heart as the source of life and faith strengthening hope}

This theme emerged from participants due to their lack of understanding concerning brain death, not considering it as death indeed. This understanding led to life expectancy and prevented organ donation, as noted in the following excerpts:

... family members ... and other people, thought that because the heart was still beating, ... we didn't want to accept ... that's why we did not donate his organs. E3

... Particularly ... my mother-in-law ... she did not understand "... she is so bealthy ... breathing, ... with a beating heart ... my danghter is normal "... for her ... if we had taken her organs it would be like we killed her ... E7

I hoped he would live ... ... when the heart is beating, we know that there is life, right? ... E8

For these family members, understanding and representing death given the warm body, with the heart beating, that moves, seemingly connected to a breathing apparatus, does not fit the concept of death that is familiar to them. Agreeing to donate in this context would be the same as to consent to the donation with their relative being still alive.

The statements also showed insecurity in the entire process of organ donation, since health professionals, who should be able to clarify doubts and demonstrate safety, would raise hope conducting dubious statements, evoking God as hope :

...The doctor said, he was very sincere, that only God could do something... but that his possibility to live was low. E3

... when we went there to know the result, he (doctor) said only God ...E8

Once again, religiosity was associated with family decision making, targeted, in this case, the belief of the reversibility of death situation, supported by faith, as seen in the statements below:

The doctor came to me and said, Mom ... you do not want to donate the organs of your son, do you? (Voice choked by tears) Never, ... because I still believe that God can do a miracle in my son's life. E1

...called pastors... prayed...the body ... began to warm ... I believed that she hoped he would still return, ... I decided not to donate anything... E4

\section{DISCUSSION}

The nucleus of social representations of organ donation for researched individuals was supported, therefore, on three points: the context of care and hospital care received; body integrity culture; and beliefs concerning life and death, those issues were linked to the knowledge of the group.

The peripheral elements that supported the representations were: unawareness of the transplant system and the process for donation; conflict of interest and failure in communication between health professionals and family; organ trafficking myth; religiosity; culture; and respect the will of the dead person.

Our findings confirm what have been described in other researches with families who have not consented to donate the organs of their family member ${ }^{(1,8)}$. Nonetheless, we showed a qualitative perspective on the realities experienced by these families.

The representations that guided this study found that the type of care provided by health services to patients and their families was essential for refusing the donation. The Brazilian Constitution guarantees all citizens the right to health care provided by the state, free of charge, without discrimination of any kind.

Conversely, the experiences reported by family members did not match the user's need for quality care, understood as welcoming and effective when communicating bad news on the part of health professionals.

In this context, there is still a strong influence of the biomedical model, with hospitals overcrowding, unsatisfactorily provision of services, consequent work overload of health workers and discomfort to population. Situation that weakens the physician-patient relationship and undermines confidence in medical practice ${ }^{(13,14)}$.

The statements of the participants showed that the relationship health professional, patient and family interfered with the process of organ donation. Families, sensing mechanicalness, team distance, feeling of lack of commitment, lack of acceptance and enlightenment, promptly responded with negative organ donation because they could not dissociate their decision to care received.

The way knowledge on organ donation was constructed by society is also crucial to determine how it represents itself. The first experiments with transplants occurred in the late 1960s in the field of medical knowledge and they were widely publicized by the media. All knowledge was based on mechanicalness replacement of body parts. Only after the 1980s, the donor and his family started being valued as fundamental parts of the process ${ }^{(4)}$.

Mass media have great power for the dissemination of scientific knowledge to the public, acting as a mediator between scientific knowledge and society. Frequently, media is responsible for communicating new information to individuals, thus defining the focus of discursive processes in society ${ }^{(15)}$.

Given this aspect of the broadcast media, it is easy to understand the representation of the inviolability of the 
body expressed by the participants, especially, anchored in a society that worships the body. The body is the concrete means of social communication: represents individuality, inherent expression to being in the world, it is as a record of the history of each one ${ }^{(16)}$.

With the advent of transplantation, the way that life and body are conceptualized was modified. Death came to represent the possibility, by donation, to save life or improve survival in patients with chronic failures, representing a new paradigm on the value of the body after death ${ }^{(17)}$.

A study ${ }^{(18)}$ conducted in the United Kingdom with 26 families who refused to donate the organs of their relatives has found that 15 of them claimed as the main factor, the protection of the dead body, not to consent, which corroborates the results of this study. The concerns were related to violation and profanation of the body, the fear of the destruction of the aesthetic image, the fear to keep in memory the image of the relative cut; the fear of an unnecessary removal and, finally, the fear the relative could suffer more ${ }^{(18)}$.

Religious beliefs may also play an important role for society in its decision on organ donation. Historically, many religions were resistant to the idea of organ donation. The Jews, for example, believed that the use of the body of the dead person was similar to adulterate the image of God. The Catholics had the vision of the mutilation of the body, and the Protestants believed in the body's need to be intact for the success in the resurrection ${ }^{(19)}$.

Today, these views are not supported due to the values of altruism that all religions have, and the reconstruction of representation, since social representations are historical in nature and influence the development of the thought of the individual over the concepts and known images ${ }^{(7)}$.

An additional factor is that the decision about organ donation occurs when there is a death, at the height of grief.

Historically, the concept of death has gone through several transformations, being initially regarded as a last breath of life and, in the 18th century, its occurrence is confirmed with the state of decomposition of the bodies. With knowledge of the bloodstream, death came to be defined by the absence of heartbeat, cessation of circulation and respiration ${ }^{(20,21)}$.

Especially for common sense, understanding of death configured as an interruption of heartbeats. With the perspective of transplantation of organs and tissues, consequently, with the removal of the heart still in contraction, broke a conceptual understanding barrier of end of life and a new approach to death emerged: brain death as the criterion to possibility of life and availability of organs and tissues for transplant ${ }^{(21)}$.

The specificity of the diagnosis of brain death that determines the death with the heart still beating, without the most famous and classic evidence of death - a cold pale body - refers to new uncertainties and mistrust in medical practice, science and the holders of these activities . For the family, it is difficult to rationally consider the dead body artificially kept in the intensive care unit $(\mathrm{ICU})^{(22)}$.

A complicating issue is the knowledge of health professionals about the diagnosis of brain death. In a study conducted in Rio Grande do Sul ${ }^{(23)}$ with 246 intensive care physicians, it was observed that $17 \%$ were unaware of the concept of brain death, which can lead to unnecessary occupation of insufficient ICU beds in the country, this shortage mentioned by family members interviewed in our study.

The family's decision given the brain death of a relative is complex, since it must be decided on a matter which the deceased relative perhaps never mentioned or maybe has never been addressed in the circle of family relationships and about which its members may have different opinions; and finally, in a moment that mourning is at the beginning ${ }^{(24)}$.

Health professionals should help families understand and accept death as a single process, being because of brain death of by asystole. At this point, what the family needs is welcoming, listening and attention of professionals ${ }^{(25)}$.

We also observed that among study participants just one of them made the decision alone, because the potential donor had expressed his desire in life, other participants took the matter to be discussed with family members, and the final decision did not necessarily correspond to the legal guardian`s decision. Our inference is that this aspect of the complexity of the decision, the family cannot or will not take sole responsibility for dissent and its possible repercussions on family and social future relationship.

It should be noted, as a possible methodological limitation, that there is a possibility participants may had memory lapses occurred under the influence of time of mourning, causing forgetfulness of some relevant facts for making the decision about the deceased organ donation.

The need for more investigations on this topic is clear, especially in other cultural, social and economic contexts, which will make the emergence of other aspects of analysis possible. Social representations are dynamic, therefore, other findings will eventually emerge from the social reconstruction on the topic of death and organ donation.

\section{FINAL CONSIDERATIONS}

Social representations which guided family decision to refuse organ donation were supported by the representation of the assistance provided to their family member, the culture of maintaining the integrity of the 
body after death, besides the lack of understanding of brain death as death indeed.

The actions of the social environment that influenced the refusal have been linked to the contrary opinions of family members, religion and the unpreparedness of healthcare professionals concerning the donation process.

We suggest that more education campaigns are conveyed by the control departments, however, that its

\section{REFERENCES}

1. Moraes EL, Massarollo MC. Reasons for the family member's. refusal to donate organ and tissue for transplant. Acta Paul Enferm. 2009; 22 (2):131-5.

2. Diretrizes básicas para captação e retirada de múltiplos órgãos e tecidos da Associação Brasileira de Transplantes de Órgãos. São Paulo: ABTO; 2009.

3. Associação Brasileira de Transplante de Órgãos. Causas da não efetivação da doação por Estado: analisadas sobre o número de não-doadores: ano 2010. Registro Bras Transpl. 2010;16(4):27.

4. Moloney G, Walker L. Talking about transplants: social representations and the dialectical, dilemmatic nature of organ donation and transplantation. Br J Soc Psychol. 2002; 41(Pt 2): 299-320.

5. Moraes EL, Massarollo MC. [Bibliometric study on family refusal of tissue and organ donation for transplants from 1990 to 2004]. J Bras Transpl. 2006; 9: 597-609. Portuguese.

6. Santos MF, Almeida LM. Diálogos com a teoria da representação social. Recife: Editora Universitária da UFPE; 2005.

7. Moscovici S. Representações sociais: investigações em psicologia social. 5a ed. Petrópolis: Vozes; 2007.

8. Moraes EL, Massarollo MC. Family refusal to donate organs and tissue for transplantation. Rev Latinoam Enferm. 2008; 16 (3): 458-64.

9. Bousso RS. [The family decision-making process concerning consent for donating their child's organs: a substantive theory]. Texto \& Contexto Enferm. 2008; 17(1): 45-54. Portuguese

10. Brasil. Ministério da Saúde. Legislação sobre transplantes no Brasil. Brasília(DF): Editora do Ministério da Saúde; 2005.

11. Fontanella BJ, Ricas J, Turato ER. [Saturation sampling in qualitative health research: theoretical contributions]. Cad Saúde Pública. 2008; 24 (1):17-27. Portuguese.

12. Bardin L. Análise de conteúdo. Coimbra: Edições 70; 2004, 226p.

13. Alves V S. [A health education model for the Family Health Program: towards comprehensive health care and model content is focused on solving society doubts concerning the definition and reliability of the diagnosis of brain death and the process of organ allocation. Besides the creation, in all services that receive critically ill patients with the perspective of evolution to brain death, of a continuing education work to health professionals focused on the appropriate family interview, welcoming and the clarification of the donation and transplantation process. reorientation]. Interface Comunic Saúde Educ. 2005; 9(16): 39-52. Portuguese.

14. Pazin Filho A. [Death: considerations for the medical practice]. Medicina (Ribeirão Preto). 2005; 38 (1):20-5. Portuguese.

15. Moloney G, Walker I. Messiahs, pariahs, and donors: the development of social representations of organ transplants. J Theory Soc Behav. 2000; 30 (2):203-27.

16. Freitas NK. [Body schemes, visual images and representations of self body: theoretical and conceptual questions]. Ciênc Cogn. 2008; 13(3):318-24. Portuguese.

17. Roza BA, Garcia VD, Barbosa, SF, Mendes KD, Schirmer J. Organ and tissues donation: relation with the body in our society. Acta Paul Enferm. 2010; 23(3):417-22.

18. Sque M, Long T, Payne S, Allardyce D. Why relatives do not donate organs for transplants: 'sacrifice" or "gift of life'? J Adv Nurs. 2008; 61(2): 134-44.

19. Rumsey S, Hurford DP, Cole AK. Influence of knowledge and religiousness on attitudes toward organ donation. Transplantation Proc. 2003; 35(8): 2845-50.

20. Kovacs MJ. Bioethics oncerning life and death. Psicol. USP. 2003; 14(2): 115-67. Portuguese.

21. Oliveira RA, Oselka G.. Terminalidade da vida: doença incurável e morte encefálica In: KOVÁCS, M.J.,ESSLINGER, I. (orgs.) Dilemas Éticos. São Paulo: Loyola: Centro Universitário São Camilo, 2008, p.81-9.

22. Sadala ML. A experiência de doar órgãos na visão de familiares de doadores. J Bras Nefrol. 2001; 23(3): 143-51.

23. Schein AE, Carvalho PR, Rocha TS, Guedes RR, Moschetti L, La Salvia JC. [Evaluation of intensivists' knowledge on brain death]. Rev Bras Ter Intensiva. 2008; 20(2):144-8. Portuguese.

24. Steiner P. A doação de órgãos a lei, o mercado e as famílias. Tempo Social Rev Sociol USP. 2004; 16 (2):101-28.

25. Knihs NS, Schirmer J, Roza BA. [Adapting the spanish transplant management model to reduce family rejection and maintain the potential donor]. Texto \& Contexto Enferm. 2011; 20 (N Espec):59-65. Spanish. 